VERTAISARVIOITU

KOLLEGIALT GRANSKAD

PEER-REVIEWED

www.tsv.fi/tunnus

\title{
OPISKELIJOIDEN OMA-ALOITTEISET SELITYSPYYNNÖT JA NIIDEN KÄSITTELY \\ - NEUVOTTELUA LUOKKAHUONEEN EPISTEEMISISTÄ OIKEUKSISTA JA VELVOLLISUUKSISTA
}

\author{
Saija Merke, Åbo Akademi
}

Pilvi Heinonen, Haaga-Helia / Helsingin yliopisto

Ulla Karvonen, Helsingin yliopisto

Tutkimus käsittelee opiskelijoiden selityspyyntöjä sekä pyyntöjen yhteydessä esitettyjä selontekoja. Tutkimuksessa vertaillaan selityssekvenssejä kolmesta eri oppimiskontekstista, joista kaksi on yliopistokursseja ja yksi yläkoulun luokkahuonetilanne. Tutkimuksen metodi on etnometodologinen keskustelunanalyysi. Analyysin perustana on selityssekvenssi, joka esitetään toiminnallisena ja tiedollisena kokonaisuutena. Aineistossa selityspyyntöä käsitellään pääosin odotuksenmukaisena ja oikeutettuna toimintana ainakin silloin, kun pyyntö palvelee senhetkistä kokonaistoimintaa ja toiminnan päämäärää. Fokuksessa ovat selityspyynnöt, joiden muotoiluun liittyy perusteluja ja täsmennyksiä tai joita joko pyytäjä tai pyynnön vastaanottaja käsittelevät epäodotuksenmukaisina suhteessa vuorovaikutustilanteen normiodotuksiin. Tutkimuksen keskeisin tulos on, että selityspyyntöihin liittyvät selonteot kertovat osallistujien tarpeesta neuvotella selityspyyntöihin ja selitystoimintaan liittyvästä episteemisestä ja moraalisesta ulottuvuudesta. Osallistujat osoittavat selityspyyntöihin liittyvillä selonteoilla, että selityspyynnöille ja selityksille tarvitaan kontekstikohtainen legitimiteetti, joka tukee selityspyynnön onnistumista tai joissain tapauksissa sanktioi pyynnön.

Avainsanat: episteemiset oikeudet, luokkahuonevuorovaikutus, selityspyyntö, selonteko

Kirjoittajien yhteystiedot:

Saija Merke

Pilvi Heinonen

Ulla Karvonen

saija.merke@abo.fi

pilvi.heinonen@haaga-helia.fi

ulla.r.karvonen@helsinki.fi 


\section{JOHDANTO}

Selittäminen eli ongelmalliseksi, epäselväksi tai muutoin tarkennettavaksi osoittautuneen seikan selventäminen tai perusteleminen on käytänne, jolla on tärkeä rooli monissa institutionaalisissa tilanteissa (ks. Antaki, 1994). Luokkahuoneen vuorovaikutustilanteissa, esimerkiksi opetuskeskusteluissa, selityksiä ja selityspyyntöjä esiintyykin melko taajaan. Selittämällä jäsennetään maailmaa ja syvennetään tai luodaan yhdessä uutta tietoa (Gosen, Berenst \& de Glopper, 2013; Karvonen, Tainio, Routarinne \& Slotte, 2015). Selittämisen taitoa ei kuitenkaan yleensä koulussa opeteta tai harjoitella erikseen (vrt. kuitenkin Gosen ym., 2013). Opiskelijoita toki rohkaistaan osallistumaan selitystoimintaan ja tuottamaan itse selityksiä niin, että he voivat saada palautetta selityksistään (Gosen ym., 2013; Morek, 2012).

Aiemmissa luokkahuonetutkimuksissa tarkastelunkohteena ovat pääosin olleet joko opettajan tuottamat selitykset tai sellaiset opiskelijoiden tuottamat selitykset, jotka käynnistyvät opettajan aloitteesta ja rakentuvat näin opettajan ehdoilla (Gosen ym., 2013; Karvonen ym., 2015). Viime aikoina on tutkittu esimerkiksi sitä, miten opettajan selitykset jäsentyvät suhteessa oppilaiden vuoroihin (esim. Koole, 2010; Koole \& Elbers, 2014). Oppilaiden aloitteesta käynnistyneisiin selityssekvensseihin on kiinnitetty huomiota siitä näkökulmasta, ratkaisevatko opettajan vastaukset oppilaan esittämän ongelmakohdan. Koole (2010) on todennut, että selitystoimintaan ryhtyminen ei takaa välttämättä toiminnan tavoitteen eli ongelman ratkaisemisen toteutumista. Toinen näkökulma on se, miten opetuskeskustelun luonne mahdollistaa oppilaan selitystä hakevan vuoron tai tarkennuksia esittävän väitteen integroimisen yleiseen keskusteluun. Opettaja ei esimerkiksi tartu opiskelijan vuoroon, jos arvioi vuoron olevan sekventiaalisesti "väärässä paikassa" tai topikaalisesti epärelevantti (Skarbø Solem, 2016). Tanner (2017) huomauttaakin, että luokkahuoneen sosiaalisen vuorovaikutuksen säännöt ja odotukset vaikuttavat opetustilanteen rakentumiseen ja samalla osallistujien mahdollisuuksiin toteuttaa onnistuneesti esimerkiksi opettajan ja oppilaan välisiä selitys- ja opetussekvenssejä.

Tässä artikkelissa tarkastelemme opiskelijoiden oma-aloitteisia selityspyyntöjä, niistä käynnistyviä selityssekvenssejä sekä sekvensseihin rakentuvia neuvotteluja opiskelijan ja opettajan episteemisistä eli tiedollisista oikeuksista ja velvoitteista. Olemme kiinnostuneita paitsi selityksistä sosiaalisena toimintana myös selityspyyntöjen moraalisista implikaatioista. Keskitymme siihen, miten opiskelijoiden käynnistämät selityssekvenssit jäsentyvät sekä miten osallistujat orientoituvat niihin ja arvioivat niitä suhteessa institutionaalisen vuorovaikutustilanteen luomiin odotuksiin. Analysoimme sitä, millä tavoin opettaja ja opiskelijat selityssekvensseissä tuovat esiin ymmärrystään tietoon ja tietämiseen liittyvistä oikeuksista ja velvollisuuksista: kenellä on mahdollisuus ja oikeus pyytää tai antaa selityksiä sekä valta määritellä, millainen selitys on oikeanlainen ja riittävä. Käsittelemme artikkelissamme kolmea esimerkkikatkelmaa, joista kahdessa toimijoiden tietoon ja sen ilmaisemista koskeviin oikeuksiin ja velvoitteisiin liittyvä yhteisymmärrys on koetuksella tai horjuu. Vastaamme empiirisen aineiston analyysin avulla seuraaviin tutkimuskysymyksiin:

1. Miten opiskelijat perustelevat oma-aloitteisia selityspyyntöjä, ja millaisia vuorovaikutuksellisia tehtäviä perusteluilla on?

2. Millä tavoin opetustilanteen osapuolet käsittelevät opiskelijan selityspyyntöä? 
Tutkimusmenetelmänämme on keskustelunanalyysi, jossa sosiaalisen vuorovaikutuksen ymmärretään rakentuvan vuoro vuorolta osallistujien yhteisenä toimintana. Analyysityökaluna toimii keskustelun sekventiaalisuus eli vuorojen jäsentyminen vieruspareiksi tai kolme vuoroa sisältäviksi sykleiksi (Raevaara, 2016; Schegloff, 2007). Selityspyyntö ja siitä alkava selityssekvenssi rakentuvat osaksi oppituntikeskustelua, ja selityspyyntö edustaa sekvenssin ensimmäistä vuoroa.

\section{SELITYSPYYNNÖT JA SELON- TEOT OPETUSKESKUSTELUSSA: NEUVOTTELUA EPISTEEMISISTÄ OIKEUKSISTA JA VELVOLLI- SUUKSISTA}

Vuorovaikutustilanteen osapuolten välisten suhteiden episteeminen eli tiedollinen ulottuvuus muodostaa yhden niistä sosiaalisista rakenteista, joihin osallistujat orientoituvat toiminnassaan, myös luokkahuoneen vuorovaikutustilanteissa (mm. Stevanovic \& Peräkylä, 2014). Käsitys siitä, keillä on pääsy puheena olevaa asiaa koskevaan tietoon, vaikuttaa siihen, millä tavoin keskustelijat vuorovaikutustilanteissa toimivat ja millä tavoin he tulkitsevat toistensa toimintaa (Heritage, 2012).

Institutionaalisessa vuorovaikutuksessa osapuolten roolit vaikuttavat heidän tiedollisiin asemiinsa. Luokkahuoneessa opettajan ja opiskelijan tiedolliset roolit ovat lähtökohtaisesti epäsymmetriset. Opettajalla odotetaan olevan institutionaalisen asemansa puitteissa tiedollinen auktoriteetti sekä opiskeltavien sisältöjen että erilaisten opiskeluun liittyvien käytänteiden, esimerkiksi oppimateriaalien valinnan ja oppilasarvioinnin suhteen. Opiskelijoilla taas nähdään olevan ensisijainen pääsy omaa oppimistaan ja opiskeluaan koskevaan tietoon sekä velvollisuus tietää niistä asioista, joita oppitunneilla on käsitel- ty. (Heller, 2017; Merke, 2016.) Nämä odotukset eivät tietenkään aina ole yhteneväisiä todellisuuden kanssa: opiskelijalla voi olla opettajaa enemmän tietoa opiskeltavasta sisällöstä, ja opettajalla voi vastaavasti olla enemmän tietoa opiskelijan oppimisesta ja siihen liittyvistä seikoista kuin tällä itsellään. Osapuolten suhteellinen pääsy tietoon samoin kuin tietoon ja tietämiseen liittyvät oikeudet ja velvollisuudet ovatkin opetustilanteissa jatkuvan neuvottelun kohteena $(\mathrm{mm}$. Candela, 1999; Lehtimaja, 2012; Thornborrow, 2002). Puheenvuoroissaan osallistujat ilmaisevat ja puolustavat ymmärrystään siitä, kenellä on mahdollisuus, oikeus ja velvollisuus tietää sekä pyytää tai antaa tietoa eri asioista eri tilanteissa, ja he voivat myös haastaa toistensa ilmaisemia odotuksia ja käsityksiä tai kieltäytyä asettumasta heille tarjoutuviin tiedollisiin positioihin (mm. Heller, 2017; Kääntä, 2014; Skarbø Solem, 2016; Stivers, Mondada \& Steensig, 2011).

Osapuolten yhteisymmärrys tietoa pyytävien tai antavien vuorojen merkityksistä perustuu olennaisesti vuorovaikutuksen taustalla olevaan, tarkasti jäsennettyyn normiverkostoon (relevance rules, Robinson, 2016), joka rakentuu ja saa vahvistusta vuoro vuorolta. Luokkahuoneessa on lisäksi perustavanlaatuisia tekijöitä, jotka luovat vuorovaikutustilannetta muovaavia normeja ja normeihin kytkeytyviä odotuksia. Yksi tekijä on luokkahuoneelle tyypillinen plenaarikeskustelun vuorottelujäsennys (Lehtimaja, 2012; Tainio, 2007). Opiskelijoiden selityspyyntöjä tulkitaan suhteessa tähän vuorottelujäsennykseen. Opiskelijoiden tietoa hakevat vuorot ovat opettajajohtoisen plenaarikeskustelun aikana odotuksenmukaisia tai ainakin sallittuja erityisesti paikoissa, joissa opetussykli on saanut päätöksensä. Siten ne edustavat toimintoja, jotka ovat oppituntikeskustelulle tyypillisiä (Merke, 2016; Waring, 2011), ja samalla puhujat tulkitsevat niiden olevan 
yhteisesti jaetun normiverkoston toimintamalleja (Garfinkel, 1967; Heritage, 1984). Selitystä pyytävässä vuorossa opiskelija asemoituu vastaanottajaa tietämättömämmäksi suhteessa selitettävään ja ilmaisee samalla ymmärrystään siitä, että vastaanottajalla on pääsy selityksen tuottamisen mahdollistavaan tietoon. Selityspyyntö myös implikoi puhujan ymmärrystä oikeudestaan pyytää ja saada tietoa ja vastaanottajan velvoitteesta vastata pyyntöön.

Yleisesti omaa puhetta ja toimintaa suhteutetaan vuorovaikutuksessa toimintamalleihin ja niihin kytkeytyvään normistoon niin, että omaa toimintaa pidetään tämän perusteella moraalisesti oikeutettuna. Samalla oletetaan myös kanssaihmisten peilaavan omaa ja muiden toimintaa siihen. Kyky ja edellytykset ymmärtää toista perustuu muun muassa luottamukseen oletetun toimintamallin olemassaolosta sekä luottamukseen siitä, että puhujat sitoutuvat toimimaan mallin mukaisesti (ks. myös Robinson, 2016). Selityspyyntöihin kytkeytyvä normisto implikoi moraalista ulottuvuutta, joka koskee muun muassa tiedon, tietämisen sekä tiedon pyytämisen vastuuta ja oikeutta. Selityspyyntöihin liittyvä moraalinen ulottuvuus nousee keskustelun pinnalle siten, että osallistujat kohtelevat itseään ja toisiaan selontekovelvollisina suhteessa jaettuihin normeihin ja erityisesti normien rikkomiseen (Hazel \& Mortensen, 2017).

Silloin, kun selityspyynnön esittäjä perustelee tai selostaa omaa pyyntöän, hän osoittaa itsensä selontekovelvolliseksi. Perusteluilla tai selostuksella puhuja implikoi, että yhteisymmärrys ei ole välttämättä taattu, ja että oma vuoro kyseenalaistaa mahdollisesti yhteistä toimintamallia ja siten yhteisymmärrystä. Etenkin yhteisymmärryksen rakentamista haittaavien rikkomusten tulkitaan kyseenalaistavan yhteisiä taustaoletuksia, mikä johtaa tilannetta normalisoiviin selontekoihin.
Vaikka rikkomukset nähtäisiinkin tietoisina, niitä pidetään ei-legitiimeinä valintoina, mistä syystä vastaanottaja voi nostaa ne vuorovaikutuksessa esille ja sanktioida. (Robinson, 2016.) Toisaalta puhuja, joka kokee haastavansa odotuksia ja taustaoletuksia tai ylittävänsä yhteisiä normeja, saattaa selittää tai perustella selonteolla omaa toimintaansa ja sitä kautta normalisoida valintojaan, esimerkiksi meidän tarkastelemissamme tapauksissa omaa selityspyyntöään (ks. myös Hazel \& Mortensen, 2017). Selontekoja (accounts, ks. esim. Heritage, 1988) pidetään yleisesti normista poikkeavan käyttäytymisen tai muuten moitittavan toiminnan merkkinä.

Selonteko voi liittyä omistettuun tietoon, mutta yhtä lailla tietämättömyyteen ja tiedon pyytämisen arkaluonteisuuteen. Osapuolet arvioivat tiedon osoittamista tai pyytämistä ja näiden legitimiteettiä kontekstikohtaisesti. Luokkahuoneessa selityspyynnön oikeutus liittyy muun muassa opetuskeskustelun agendan vaiheeseen ja meneillä olevaan toimintaan. Koole ja Elbers (2014) toteavat, että opettajan tapa käsitellä yksittäisen oppilaan selitys- tai avunpyyntöä on yhteydessä myös muihin oppilaisiin ja heidän tarpeisiinsa sekä opetustilanteen toimintavaiheeseen. Oppilaan avunpyyntöön vastaaminen ei kuitenkaan välttämättä merkitse tarpeellisen avun antamista. Oppilaan pelkkä ymmärtämättömyyden osoitus voi johtaa siihen, että opettaja tulkitsee ongelman ainoastaan proseduraaliseksi eikä sisällölliseksi. Tästä voi seurata, että opettaja muotoilee selityssekvenssin sulkevan vuoron niin, että oppilaan uusi ymmärtämättömyyden osoitus tai avunpyyntö on opettajan vuoron jälkeen sekvenssin kannalta odotuksenvastainen (Koole, 2010; Tanner, 2017), jolloin oppilaan alkuperäinen ongelma ei välttämättä tule ratkaistuksi.

Osallistujat arvioivat selityspyyntöjä siltä kannalta, onko selityksen tai tiedon pyytäminen nimenomaisesta asiasta ja siinä muodos- 
saan perusteltua ja aiheellista eli hyväksyttävissä. Jotta opiskelijan selityspyyntöön vastattaisiin seuraavassa vuorossa, selityspyynnön on oltava kontekstissaan sopiva ja ymmärrettävä. Ilman selontekoa esitetty selityspyyntö esitetään ongelmattomana, ja se luo odotuksen ongelman todennäköisestä selvennyksestä. Selityspyyntöä tukeva ja perusteleva selonteko sen sijaan osoittaa vuoron olevan tavalla tai toisella odotustenvastainen. Selonteko voi myös lisätä pyyntövuoroon merkityksen kyseenalaistaa tai kritisoida toisen osallistujan toiminnan oikeellisuus tai oikeutus.

Aiemmassa luokkahuonevuorovaikutuksen tutkimuksessa selontekojen on osoitettu linkittyvän tietämisen osoittamiseen oppituntitilanteissa (Jakonen, 2014a). Jakosen (2014a) mukaan vieraskielisessä opetuksessa opiskelevat oppilaat voivat perustella esittämäänsä (kieli)tietoaan luokkahuoneen ulkopuolisilla kokemuksilla ja siten orientoitua tietoon ja tietämiseen liittyviin normiodotuksiin luokkahuoneessa. Oppilas voi esimerkiksi identifioida omaksumansa englanninkielisen käsitteen lähteeksi videopelin ja sitä kautta legitimoida tilanteessa "liiallista" tietämistään, joka voi luokkayhteisössä olla paikoin sosiaalisesti stigmatisoivaa (Jakonen, 2014a; ks. myös Jakonen, 2014b). Tietämisen ja osallistumisen normit voivat siis olla osittain hyvinkin kontekstikohtaisia ja riippua nimenomaisesta opetusryhmästä. Luokkahuonekontekstissa normiylitykset voivat koskea muitakin asioita kuin (ei-)tietämistä ja vuorottelujäsennystä. Haasteena voi pitää sitä, että normiverkoston näkymättömiä sääntöjä harvoin eksplikoidaan. (Hazel \& Mortensen, 2017.) Tiedon pyytämiseen ja hakemiseen liittyvät selonteot osoittavat, että osallistujat ovat tietoisia normiverkostosta ja samalla orientoituvat siihen, että normiylityksistä voi seurata sosiaalista stigmatisoitumista.

\section{AINEISTO JA MENETELMÄ}

Tutkimusaineistomme koostuu videoaineistoista, jotka on kerätty kolmesta erilaisesta oppimiskontekstista. Ensimmäinen osa-aineisto koostuu ranskalaisen yliopiston suomi vieraana kielenä -oppitunneista (yhteensä 12 oppituntia). Aineisto on kerätty kahdelta vuosikurssilta kahden viikon ajan. Molemmilla kursseilla toimii sama suomenkielinen opettaja. Toinen osa-aineisto käsittää 9 kuvattua oppituntia suomalaisesta pääkaupunkiseudulla toimivasta yläkoulusta historian ja yhteiskuntaopin sekä äidinkielen ja kirjallisuuden oppiaineen tunneilta. Aineistossa on mukana kaksi opettajaa (tarkemmat tiedot, ks. Heinonen, 2017). Kolmas osa-aineisto on kerätty suomalaisen yliopiston opettajankoulutuksessa, ja se käsittää noin 70 tuntia luento- ja ryhmäopetusta. Kaikki kolme aineistoa on kerätty väitöstutkimusten aineistoksi ${ }^{1}$.

Analysoimme tutkimusaineistoamme keskustelunanalyysin tarjoamin menetelmin (ks. esim. Sidnell \& Stivers, 2012; Stevanovic \& Lindholm, 2016). Analyysiämme taustoittaa näin ollen etnometodologinen, keskustelunanalyyttinen tutkimusote, jossa vuorovaikutusta tarkastellaan osallistujien orientaatioista ja vuorovaikutustilanteisiin rakentuneista normiodotuksista käsin: molemmat osapuolet orientoituvat ja odottavat toistensa orientoituvan jaettuna pidettyyn käyttäytymisen malliin ja sitä ohjaaviin normeihin.

Artikkelissamme tarkastellaan opiskelijoiden aloitteesta käynnistyneitä selityssekvenssejä eli toimintajaksoja, jotka jäsentyvät selitystä pyytävän vuoron ja selityspyyntöön vastaavan vuoron ympärille. Selityssekvenssi

\footnotetext{
1 Kaikki aineistoissa esiintyvät opettajat ja opiskelijat ovat antaneet suostumuksensa videoaineiston keräämiseen ja sen tutkimuskäyttöön. Lisäksi alaikäisten oppilaiden huoltajilta on pyydetty suostumus. Osanottajien anonymiteetin varmistamiseksi nimet ja muut tunnistamisen mahdollistavat tekijät on esimerkeissä muutettu.
} 
on kolmiosainen: Se alkaa opiskelijan esittämästä kysyvästä vuorosta, ${ }^{2}$ jossa jokin seikka osoitetaan selitettäväksi ja selityksen tuottamisesta tehdään näin relevantti seuraava toiminto. Kysyväksi muotoiltu vuoro luo odotuksia siitä, millainen vastausvuoro täyttää edellä luodun tiedon aukon ja tyydyttää selityksen tarpeen. Selityspyynnön vastaanottaja voi vuorollaan joko vastata näihin odotuksiin tai hylätä selityksen pyytäjän asettamat odotukset, esimerkiksi olla vastaamatta ja selittämättä. Opiskelijan aloitteen jälkeen opettaja tyypillisesti tuottaa selittävän vuoron tai vuoroja. Prototyyppisessä sekvenssissä selittävää vuoroa seuraa selityspyynnön esittäneen opiskelijan kuittaus eli selityksen hyväksyminen kolmannen position vuorossa. Tässä artikkelissa tarkastelussamme ovat opiskelijoiden selityspyynnöistä käynnistyvät sekvenssit, jotka sisältävät selityspyyntöön liittyviä perusteluja tai täsmennyksiä. Käsittelemme näitä vuoroja analyysissä selkoa tekevinä vuoroina, joilla otetaan kantaa selityspyynnön taustaan ja oikeutukseen. Selontekovelvollisuuden alaisiksi esimerkeissämme voidaan asettaa kuitenkin sekä opiskelija että opettaja ja heidän toimintansa. Selityspyynnöt on aineistoesimerkeissämme merkitty harmaalla taustalla ja selonteot on lihavoitu.

Ensimmäinen esimerkkikatkelmamme edustaa aineistossa frekventtiä miksi-interrogatiivilla alkavaa selityspyyntöä. Toinen ja kolmas esimerkkikatkelmamme eivät edusta aineistoissamme yhtä tyypillisiä selitysjaksoja, vaan ne on valittu analysoitavaksi, koska ne havainnollistavat hyvin tarkastelun kohteena olevaa ilmiötä. Tarkastelemalla selityssekvenssejä erityppisissä luokkahuoneaineis-

\footnotetext{
2 Kysymys on terminä ongelmallinen, koska sillä voidaan viitata sekä vuoron syntaktisiin piirteisiin että toimintaan, jonka ei tarvitse syntaktisesti olla kysymysmuotoinen. Vuoro voidaan siis tuottaa ja ymmärtää kysyväksi, vaikka se ei sisältäisi kysyvää ainesta eli kysymyssanaa tai kysyvää liitepartikkelia (Hakulinen, 2016).
}

toissa pääsemme suhteuttamaan toisiinsa selityspyyntöjen käsittelyn mekanismeja sekä selityspyyntöihin kytkeytyviä moraalisia implikaatioita eri koulu(tus)konteksteissa.

\section{TULOKSET}

Seuraavaksi analysoimme kolmea aineistokatkelmaa, joista ensimmäisessä opiskelija esittää selityspyynnön ongelmattomana, ja sellaisena sitä käsittelevät myös muut osallistujat. Toisessa esimerkissämme opiskelija esittää selityspyyntönsä ongelmattomana, mutta siihen vastaava opettaja osoittaa käsittelevänsä pyyntöä potentiaalisesti ongelmallisena. Kolmannessa esimerkkikatkelmassamme opiskelijan selityspyynnön vastaanottava opettajankouluttaja vastaavasti osoittaa käsittelevänsä pyyntöä odotuksenvastaisena ja ei-oikeutettuna ja tekee kysyjästä selontekovelvollisen. Jokaisen esimerkin kohdalla esittelemme aluksi meneillään olevan pedagogisen toiminnan, josta käy ilmi opetustilanteen kokonaistoiminta ja toiminnan tavoite, sillä sekvenssin etenemisen kannalta on merkittävää, onko ryhmä tarkastelemassa kotitehtäviä ja harjoittelemassa juuri opittua asiaa, tarkistamassa palautettua koetta vai valmistautumassa tenttiin.

\subsection{Selityspyynnön käsitteleminen oikeutettuna - responssina selitys}

Ensimmäinen esimerkki on ranskalaisaineistosta, ja siinä toteutuu aineistossamme melko tavanomainen selityssekvenssi. Selityspyyntöön vastataan seuraavissa vuoroissa niin, että epäselvä kohta otetaan käsittelyyn. Selityspyynnön esittäjä osoittaa sekvenssin lopussa myös ymmärrystä ja selittävän vuoron hyväksynnän, mikä osoittaa, että ongelma on ratkennut. Samalla hyväksyvä vuoro mahdollistaa sekvenssin sulkemisen. Toisaalta selityksen pyytäjä esittää selityspyynnön yhteydessä lisäperustelun, mikä viittaa siihen, että seli- 
tyksen pyytäjä arvioi pyynnön yksin riittämättömäksi ja tukee perustelullaan pyynnön ymmärrettävyyttä.

Esimerkki on opintojaksolta, jossa ryhmä on opiskellut omistusrakennetta ja tarkastellut rakenteen soveltamista oppikirjatekstien avulla. Opetustilanteen toimintavaihe on opiskelijoita aktivoiva: opiskelijoiden ei tarvitse erikseen pyytää puheenvuoroa, sillä oma-aloitteinen kysyminen on toiminnan kannalta legitiimiä. Toiminnalla tavoitellaan rakenteen syvempää ymmärtämistä niin, että opiskelijoita harjaannutetaan rakenteen tunnistamiseen ja samalla kartoitetaan mahdollisia ymmärtämisongelmia. Konkreettisesti osallistujat ovat kääntämässä lyhyitä suomenkielisiä oppikirjadialogeja ranskan kielelle. Tämän esimerkin ymmärrysongelma ja selityksen tarve syntyy morfologisten päätteiden tunnistamisesta. Dialogissa lekseemi satanen esiintyy partitiivimuodossa satasta, kun taas viisikymppinen on nominatiivissa. Selityspyyntö ei siis koske harjoiteltavaa omistusrakennetta vaan dialogissa esiintyvien lekseemien morfologisten päätteiden läpinäkyvyyttä ja semantiikkaa. Molemmat lekseemit ovat substantiivijohdoksia, ja nen-johdin tuo sanamuotoihin rahasetelin merkityksen. Esiintymät ovat samaa johdostyyppiä mutta eri sijamuodoissa, mikä johtaa siihen, että satasta-muodon kuuluminen nen-loppuisiin nomineihin on osalle opiskelijoista epäselvää.

\section{[1] "Satasta"}

1. ope: minulla ei ole satasta.

2. Lucie: ¡je n'ai pas de [billet de cent ${ }^{\circ}$

3. Hélène: $\quad\left[{ }^{\circ}\right.$ je n'ai pas de billet de cent ${ }^{\circ}$

4. ope: oui

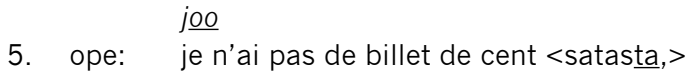
minulla ei ole satasta

6. vous reconnaissez le partitif oui? c'est en fait te tunnistatte partitiivin eikö? se on itse asiassa

7. c'est un mot avec $\uparrow n$ e $n$ ฟà la fin, se on nen-loppuinen sana

8. donc ça fait un parti»tif comme ça, eli se tekee tuollaisen partitiivin

9. j'ai pas de billet de cent, minulla ei ole satasta

10. minulla on varin viisikymppinen

11. ?: j'ai seulement un billet de cinquante

12. Lucie: j'ai se[ulement (-) minulla on vain (-)

13. ope: [j'ai seulement un billet de cinquante oui minulla on vain viisikymppinen kyllä

14. Gaëlle: ${ }^{\circ}$ et pourquoi ça se construit pas sur le même euh $>$ des $\uparrow \sin$ enfin. $<^{\circ}$ ja miksi sitä ei muodosteta saman mallin mukaan siis

15. cent et cinquante là dedans il y a pas un mot sata ja viisikymmentä eikö siinä ole sanaa

16. qui veut dire bil $\uparrow$ let $\downarrow \mathrm{ou}^{\circ}$, joka merkitsee seteliä vai

17. ope: hh. [äm ää ] ((kääntyy taululle ja alkaa kirjoittaa))

18. Lucie: [c'est (-) ça] se on (-) tuo 


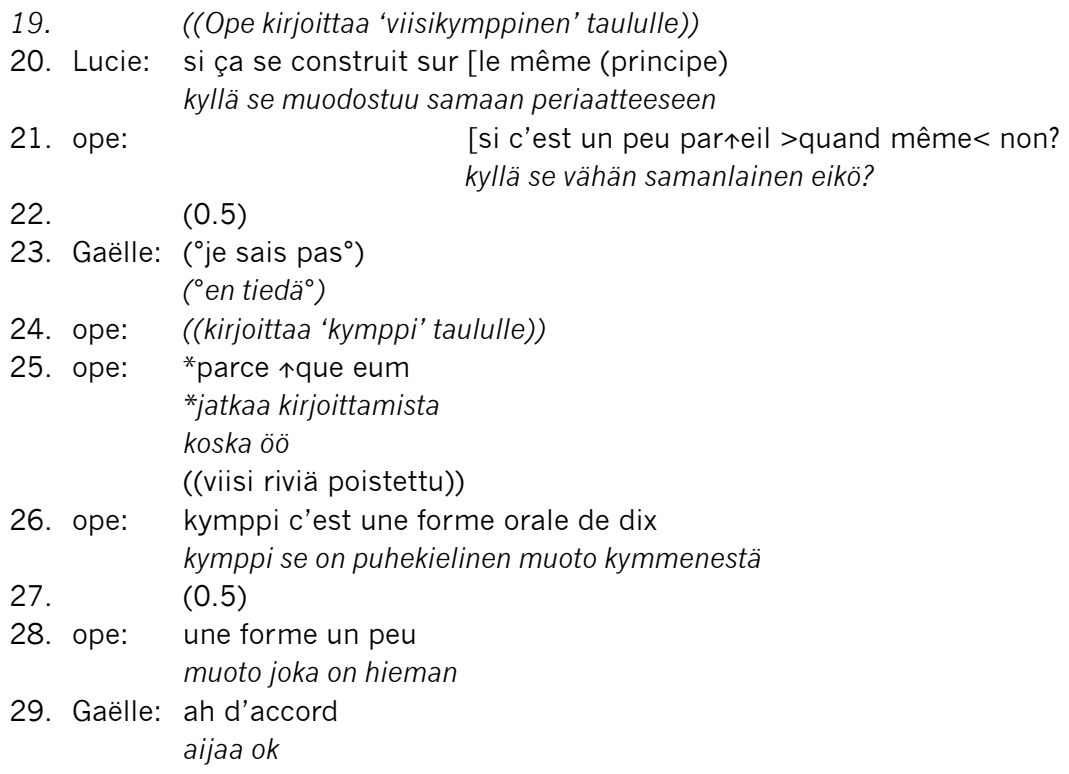

Katkelman alussa opettaja lukee käännettävät dialogikohdat (r. 1 ja 10). Opiskelijat vastaavat tehtävään suoraan ilman vuoron pyyntöä tai erillistä kehotusta (r. 2-3 ja r. 11-12). Gaëllen selityspyyntö (r. 14) on kohdassa, jossa edellinen dialogin repliikki on käsitelty loppuun niin, että vuoro ei keskeytä meneillään olevaa oikeamuotoisen käännöksen käsittelyä. Vuoro on muotoiltu kielteiseksi miksi-kysymykseksi, mikä on tässä aineistossa tavanomainen tapa muotoilla selityspyyntö (Merke, 2016). Sekä kielto että miksi-kysymyssana implikoivat, että lekseemien epäyhtenäiset muodot ovat vastoin Gaëllen odotuksia. Hän perustelee odotuksiaan samassa vuorossa selonteolla (r.15-16) ja täsmentää, mikä hänen mielestään olisi ollut odotuksenmukaista: lekseemeissä pitäisi olla analogia, sillä molemmat viittaavat rahaseteleihin. Gaëllen muotoilema selityspyyntö viittaa siihen, että hän kaipaa kielelle johdonmukaisuutta, jota siinä nyt ei ole.

Opettaja reagoi välittömästi selityspyyntöön sisäänhengittämällä ja lausumalla vuo- ron alun, jota hän ei kuitenkaan vie verbaalisesti loppuun (r. 17). Sen sijaan hän kääntyy ja kirjoittaa vaikeuksia tuottavat lekseemit taululle. Lucie kuitenkin reagoi ja hylkää Gaëllen esittämän väitteen siitä, että lekseemeitä ei muodostettaisi saman mallin mukaan (r. 20). Lucie ei siis kyseenalaista itse Gaëllen selityspyyntöä tai sen ajankohtaa vaan ainoastaan pyynnössä esitetyn lekseemejä koskevan väitteen. Ainakin kaksi osallistujaa, joista toinen on opettaja, hyväksyy Gaëllen osoittaman selityspyynnön ottamalla asian käsittelyyn. Gaëllen väärinkäsitystä kommentoi ensin opiskelutoveri, minkä jälkeen opettaja vasta ottaa kantaa, joskin lievennetyllä muotoilulla: c'est un peu pareil quand même non', se on vähän samanlainen eikö (r. 21).

Katkelmassa on kaksi tekijää, jotka tekevät selityspyynnöstä oikeutetun ja paikallisessa kontekstissaan sopivan ja ymmärrettävän. Ensiksi: kokonaistoiminnassa on kyse yhteisestä projektista, jonka tavoite on tehdä suomenkielinen oppikirjadialogi kaikille opiskelijoille ymmärrettäväksi. Selityspyyntö 
tukee meneillään olevaa toimintaa, koska sen avulla pyydetään tarkennuksia ja selvennyksiä. Toiseksi: selityspyyntö on sekventiaalisesti paikassa, jossa opettaja on juuri hyväksynyt edellisen käännöksen oikeaksi. Tehtävän puolesta ryhmä on valmis ottamaan seuraavan askeleen (ks. myös Jacknick, 2011). Gaëllen selityspyyntö koskee tehtävään sisältyvässä dialogissa olevan vuoron morfologiaa, mikä tarkoittaa, että selityspyyntö on sekä sisällön kannalta että sekventiaalisesti oikeassa kohdassa, joskaan selityspyyntö ei liity tunnilla käsiteltyyn omistusrakenteeseen. Gaëllen ei silti tarvitse tarkentaa, mitä asiaa ongelma koskee, vaan ongelma ilmenee juuri käsitellyn repliikin sanoista. Se, että selityspyyntövuoroa ei silti käsitellä täysin ongelmattomana vaan sen sisältämä väite kyseenalaistetaan, johtuu ongelmaan liitetyistä "vääristä" perusteluista. Esimerkissä tunnusmerkkistä on toisen opiskelijan esittämä vastalause, joka kohdistuu selityspyynnössä olevaan moitteeseen kielen epäjohdonmukaisuudesta.

Lucien vuoro (r. 20) osoittaa, että vaikka selityspyyntö on toiminnallisesti ja sekventiaalisesti sopivassa paikassa, on muitakin tekijöitä, jotka tekevät selityspyynnöstä oikeutetun ja legitiimin. Jos selityspyyntöön itsessään sisältyy kritisoiva toiminta tai tässä tapauksessa implisiittinen moite, selityspyyntöä tarkastellaan tämän kritiikin näkökulmasta. Kyse on siis siitä, onko selityspyyntöön sisällytetty kritiikki tai kritisoiva toiminta legitiimiä joko aiheen tai kokonaistoiminnan kannalta. Tässä tapauksessa kritiikki kohdistuu kieleen ja sen johdonmukaisuuteen. Opettaja todistaa kritiikin olevan aiheetonta kirjoittamalla morfologian osat taululle, joskin jättää selittämättä seteli-lekseemin puuttumista.

Yleisesti selityspyyntö asettaa niin selityksen pyytäjän kuin vastaanottajankin vastuuseen. Selitettävän osoittava osallistuja on vastuussa siitä, että tarve käsitellä selitettävää on siinä kohdassa kokonaistoimintaa sekä ymmärrettävä että re- levanttia. Osallistujien täytyy pystyä ymmärtämään, miksi selityspyyntö esitetään nimenomaisessa kohdassa. Pyynnön pitää myös perustua oikeisiin taustaoletuksiin. Siinä tapauksessa, että osallistujat arvioivat selityspyynnön tarvetta tai selontekoon liittyvää taustatietoa eri tavalla, osallistujat saattavat julkisesti haastaa selityksen pyytäjää tai kyseenalaistaa selonteossa esitettyä kritiikkiä. Molemmat toiminnat asettavat selityksen pyytäjän haavoittuvaiseen asemaan, jossa pyytäjän pitää puolustaa oman toimintansa oikeutta yksin ilman ryhmän tukea.

\subsection{Selitys-ja selontekopyynnön eksplikoitu odotuksenmukaisuus}

Toinen tarkasteltava esimerkki on suomalaisesta yläkoulusta 9. luokan historian ja yhteiskuntaopin oppitunnilta. Edellä analysoitu esimerkki edusti selityspyyntöä, johon kuuluva selonteko liittyy opeteltaviin asiasisältöihin. Tässä esimerkissä selityspyyntöön kuuluva selonteko sen sijaan liittyy toimijoiden oikeuksiin ja velvollisuuksiin. Esimerkissä 2 opettaja ottaa opiskelijan tuottaman selityspyynnön käsiteltäväksi ja samalla eksplikoi selityspyynnön odotuksenmukaiseksi suhteessa meneillään olevaan kokonaistoimintaan.

Käynnissä on kokeentarkastustilanne. Opettaja on palauttanut opiskelijoille arvioimansa kokeet ja käy nyt läpi oikeita vastauksia pyytämällä oikein vastanneita opiskelijoita lukemaan vastauksensa ääneen. Tarkasteltava sekvenssi käynnistyy Ninan kysymysvuorosta, jonka funktio on samalla selityspyyntö (r. 10): Nina toteaa koevastauksensa olevan aivan samanlainen kuin täydet pisteet saaneella luokkatoverilla ja pyytää selitystä kokeen pisteytykseen ja täsmennystä siihen, mitä koevastauksesta on jäänyt puuttumaan. 
[2] "Vähän väärinpäin” (suomalainen peruskoulu, 9. luokka, historia ja yhteiskuntaoppi)

1. ope: El:: vika mut siis >palvelutase Leila paljos sul oli<

2. Leila: ää neljä?

3. ope: sul oli neljä, neljä sanoppas mitä sä oot kirjottanu sinne.

4. Leila: öö ihmisten käyttämä rahamäärä palveluihin ja

5. hyödykkeisiin, esim ma- matkailutase ja se on se et mittaa

6. kuinka paljon rahaa liikkuu Suomeen ja Suomesta po:is, ja

7. mitataa paljonko Suomest käytetää rahaa ulkomailla ja

8. kotimaassa ja ulkomailla esim Suomessa sillee (..)

9. ope: loistavaa?

10. Nina:--> no mul on ihan samallail täällä.

mitä mult puuttuu.*

*OPEN KATSE NINAAN, HYMYILEE

11. Veera: on mulki suunnillee,

12. ope: ..> tuo tuo tarkastettavaks, ${ }^{*}$ sen takii just t- täällä nyt

$13 . \quad$ ollaa?

*TEKEE KUTSUVAN KÄDENLIIKKEEN

14. Nina: mul lukee ulkomaankaupan maksujen ja suoritusten vertailua,

15. >matkailutase, $<$ jossa vertaillaan (.-) on yhtä kuin jos

16. ulkomaalaiset käyttävät enemmän palveluita Suomessa kuin

17. u- suomalaiset ulkomailla Suomihan voittaa, (.) ihan

$18 . \quad$ samallail.

19. ope: tuos tänne,*

*TEKEE KUTSUVAN KÄDENLIIKKEEN

mä katon sen (.) loppulauseen siit, must

20. tuntuu et se meni vähän nyt väärinpäin*

*OJENTAA KÄTTÄ,OTTAA VASTAAN PAPERIN

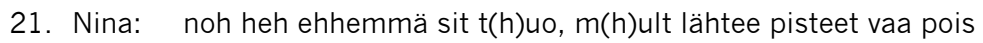

22. heh heh he=

23. ope: =en mä niit pisteitä pois ota mut (.) mth

24. (4.0) OPE LUKEE KOEPAPERIN VASTAUSTA

25. ope:-> ei kato ku tää on ulkomaankaupan maksujen ja suoritusten

$26 . \quad$ vertailua?

27. Nina: >mitä siel muka luki<

28. (3.0) OPE LUKEE KOEPAPERIN VASTAUSTA

29. ope:-> koska nyt täs on se pääomakorvausten tase, mun mielest

30. vähän menny, s- maksujen ja suoritusten vertailua?*

*NOUSEE YLÖS,PALAUTTAA PAPERIN

31. Nina: eikä ole ${ }^{\circ}$ no siellähä lukee ${ }^{\circ}$

32. ope: nii kato ihmisten käyttämä rahamäärä palveluihin ja

${ }^{\circ}$ hyödykkeisiin ${ }^{\circ *}$

*SELITTÄÄ OPPILAALLE SEISTEN PULPETIN VIERELLÄ

33. ja tääl on maksut ja suoritukset se on se pääomakorvausten

34. tase mihin se on menny pikkasen niiku sekasin.

35. Nina: mul on se paljo se (.)

36. ope:-> o:n mut siin [ei puhuta kato niist ] palveluista,*

37. Juhani: [onks nää kaikki vihkossa,]

*PALAA OPETTAJANPÖYDÄN LUO

38. ope: =on (.) TAlouden eri suhdanteet siit on lähes jokainen

39. [saanu lähes täydet pisteet, eikö ollukki?]

40. Nina: [eiku mul on palveluita ja suomalaiset käyttävät enemmän

41. palveluita ulkomailla (.-)]

42. ope: nii mut se alku menee jotenki mun mielest sekasin sen

43. pääomakorvausten taseiden [kanssa.

44. Nina:

[älä oo noin pikkut(h)arkka,

45. ope: pitää se olla? 
Selityspyynnössään Nina identifioi selitettävän eli koetehtävän vastauksen muodon, mikä näkyy vuoron kysymyksenmuotoilussa (mitä mult puuttuu, r. 10). Vuorollaan opiskelija hakee paitsi selitystä koevastauksen tavoitellusta muodosta, myös varmistusta kokeen pisteytyksen oikeudenmukaisuudesta. Nina aloittaa vuoron selkoa tekevällä väitteellä, joka nojaa edelliseen Leilan vuoroon (no mul on ihan samallail täällä). Sekventiaalisessa kontekstissaan selityspyyntö voidaan tulkita yhtä aikaa sisällöllisestä näkökulmasta selitystä hakevana ja toiminnallisesta näkökulmasta selontekoa hakevana (vrt. esim. Heritage, 1988).

Opettaja vastaanottaa selitys- ja selontekopyynnön aluksi katseella ja hymyilemällä mutta hyväksyy kuitenkin selitys- ja selontekopyynnön heti toisen oppilaan tuotettua Ninan vuoroon yhtyvän responssin (on mulki suunnillee, r. 11). Opettaja kehottaa Ninaa tuomaan koevastauksen opettajan nähtäväksi (tuo tuo tarkastettavaks, r. 12) ja eksplikoi sitten selonteolla selityspyynnön odotuksenmukaisuuden suhteessa kokonaistoimintaan (sen takii täällä nyt ollaan). Eksplikoimalla selityspyynnön relevantiksi opettaja paitsi vahvistaa selityspyynnön hyväksytyksi myös samalla metakommentoi meneillään olevaa pedagogista toimintaa. Selonteossa esille nouseva metakommentointi voidaan tässä nähdä yhdentyyppisenä normalisoinnin strategiana (vrt. Lawrence, 1996), jolla opettaja osoittaa toiminnan odotuksenmukaisuutta institutionaalisessa vuorovaikutuskehyksessä ja sitä kautta orientoituu tilanteessa opiskelijan potentiaalisesti arkaluonteiseen selityspyyntöön. Nina reagoi opettajan kehotukseen lukemalla ääneen koevastauksensa (r. 14-18). Opettaja toistaa kehotuksensa ja paikantaa samalla vastauksen ongelmakohdan (tuos tänne, mäkaton sen (.) loppulauseen, r. 19). Opettaja siis täsmentää ensin koevastauksesta spesifin selitettävän ja tuottaa sen jälkeen useita selittäviä vuoroja, jotka ovat vuoron pintatasolla tunnistettavia selitysvuoroja esimerkiksi selittämiseen konventionaalistuneista partikkeleista (ei kato ku, koska nyt täs on se, niin kato, mut siin ei pubuta kato niist, r. 25, 29, 32, 36; ks. Hakulinen \& Seppänen, 1992).

Selityssekvenssi rakentuu tässä esimerkissä moniosaiseksi, sillä Nina ei hyväksy opettajan ensimmäistä selitysvuoroa (ei kato ku tää on ulkomaankaupan maksujen ja suoritusten vertailua, r. 25). Sen sijaan hän asettaa epäilyksenalaiseksi opettajan tulkinnan koevastauksen puutteellisuudesta, mikä näkyy vuoronmuotoilussa (mitä siel muka luki; VISK $\$ 1495$; muka-partikkelista ks. Nordlund, 2011). Nina jatkaa vastaan argumentoivalla vuorolla: hän puolustaa omaa kantaansa vedoten koevastaukseensa (joskin hiljaisella äänellä) ja vahvistaa vuoroaan kliittisellä sävypartikkelilla (no siellähän lukee, r. 31). Yhteisymmärryksen saavuttaminen vaatii tässä sekvenssissä neuvottelua ja samalla pitkittää selityssekvenssin. Opettaja pyrkii päättämään sekvenssin kehollisilla keinoilla (r. 30, 36) ja topikaalisella siirtymällä (r. 38). Opiskelija ei kuitenkaan mukaile opettajan toimintalinjaa, vaan palaa opettajan tuottaman siirtymän jälkeen vielä uudelleen käsittelemään koevastaustaan ja referoi sitä (eiku mul on --, r. 40). Opettajan niin mut-alkuinen uudelleenmuotoiltu vuoro (r. 42-43), jossa hän hyväksyy osan opiskelijan vastauksesta mutta samalla täsmentää vielä uudelleen ongelmakohdan (se alku, r. 42), mahdollistaa lopulta sekvenssin päättymisen ja ainakin näennäisen samanmielisyyden saavuttamisen.

Selityssekvenssin pitkittyminen selittyy mahdollisesti osin sillä, että sekvenssissä käsitellään samanaikaisesti selitys- (sisällöllisesti odotuksenmukainen koevastaus) ja selontekopyyntöä (koepisteytyksen oikeudenmukaisuus). Samalla selityssekvenssi palvelee kuitenkin meneillään olevan kokonaistoiminnan tavoitteita: koevastausten muotoilua ja sitä kautta opeteltavien sisältöjen hahmottamista 
ja kokeen pisteytysten tarkastamista. Kuten edellä analysoitu esimerkki ( 1 , Satasta), myös tämän esimerkin selityssekvenssi rakentuu yhteistoiminnalliseksi: opiskelija on mukana aktiivisena toimijana ja tiedonmuotoilijana ja rakentaa yhdessä opettajan kanssa ymmärrystä selitettävästä opetussisällöstä ja koevastauksen oikeellisuudesta (ks. esim. r. 14-18 ja r. 40-41; vrt. edellinen esimerkki r. 20). Kun oppimista (tai oppimisen mahdollistavia tilanteita) tarkastellaan muuttuvan ja tilanteessa emergoituvan osallistujuuden näkökulmasta (ks. esim. Majlesi \& Broth, 2012; Melander \& Sahlström, 2009), oppilaan aloitteesta käynnistynyt selityssekvenssi osoittautuu siis hedelmälliseksi. Samalla tämän esimerkin selityssekvenssi rakentuu toiminnallisesti ja sisällöllisesti edellistä esimerkkiä kompleksisemmaksi: koska opettajan tuottama selitys nojaa ennen kaikkea oppilaan vastauksen puutteellisuuden osoittamiseen ja mallivastaukseen (r. 4-8) vertaamiseen, sekvenssissä jossain määrin korostuu opettajan tuottama selonteko toimintansa oikeutuksesta. Vaikka opiskelijan tarjoama näkökulma koevastauksen oikeaan muotoiluun saa sekvenssissä tilaa, samanaikaisesti tapa, jolla opettaja käsittelee tilanteessa opiskelijan selitys- ja selontekopyyntöä (pyynnön norminmukaisuuden eksplikointi, stereotyyppiset selitysvuorot), osoittaa opettajan orientoituvan tilanteessa osallistujarooliinsa tiedollisena ja toiminnallisena auktoriteettina. Sekvenssin lopussa myös opiskelija osoittaa implisiittisesti orientaatiota opettajan tiedolliseen auktoriteettiin, joskin huumori-moodissa (r. 44, älä oo noin pikkut(b)arkka).

\subsection{Opiskelijan selityspyynnön käsitteleminen odotuksenvastaisena}

Kahdessa edellä analysoidussa esimerkissä selityspyyntö otetaan käsiteltäväksi ja opiskelijan esittämä ongelma tulee ratkaistuksi. Kolmannessa esimerkkikatkelmassamme opettajankouluttaja sen sijaan käsittelee opiskelijan esittämää selityspyyntöä ongelmallisena. Katkelma on opintojen ensimmäisen vuoden alkupuolen luentokurssilta. Kurssin viimeinen luento on lopuillaan ja lähestyvä kurssitentti on tutkimuksessa seurattujen opiskelijoiden yliopisto-opintojen ensimmäinen tentti. Opiskelijat ovat keskenään pohtineet monesti sitä, millaisia asioita tentissä kysytään ja millaisia vastauksia kysymyksiin odotetaan. Myös tenttikirjallisuudesta vallitsee epätietoisuutta, eivätkä opiskelijat ole varmoja siitä, mitkä kurssikuvauksissa mainituista kirjoista ovat pakollisia ja mitkä taas vapaaehtoisia. Lisäksi yksi tenttikirjoista on osoittautunut fokusopiskelijoille haastavaksi sisältönsäkin puolesta, ja sen tiimoilta on käyty jonkin verran keskustelua informaaleissa vuorovaikutustilanteissa. Viimeisen luennon loppupuolelle opettajankouluttaja on varannut aikaa tenttiä koskeville kysymyksille, joita opiskelijat esittävätkin runsaasti. Katkelman alussa (r. 1) opettaja vastaa edellisen opiskelijan kysymykseen, joka käsittelee tenttikirjan painosta ja antaa sitten puheenvuoron Merille, joka on nostanut kätensä pystyyn. 
[3] "Se Laatikaisen kirja" (LO-koulutus, luento, yliopisto)

1. ope: minkä tahansa löydätte (.) ole hyvä

2. Meri: ööh, (0.6) siihen tenttiin oli se hyvä opettaja? (1.8) ja

3. (0.4) se t- (.) kirja? (0.4) onks siit ollu jotain niinku

4. tääl vai onks se jotenki ^tukemas vai mikä sen niinku,

5. (1.0) point[ti on?]

6. ope: [hyvä opet-] onkse se Laatikaisen kirja

7. opisk1: o

8. $\quad(0.6)$

9. ope: no eikö se Laatikainen oo samoista asioista höpöttäny ku

10. minäki »täällä

11. opisk2: ${ }^{\circ}$ joo ${ }^{\circ}$

$12 . \quad(2.0)$

13. ope: ei kai siel oo mitään niinku täysin, (1.6) \#e- \#erinlaista

14. (1.8) näkökantaa.

$15 . \quad(1.0)$

16. Meri: niinku, (1.4) onkse niinku <tutkimus> se kirja

17. <kokonaisuudessaan> kertookse jostain sen tutkimuksesta?

18. (2.0)

19. ope: e- etkö ole nähnyt kirjaa.

20. Meri: no oon ja lukenukki mutta

21. opisk :hahhaehehe $£$ [hahhahhah]

22. Meri: [mutku£(h)£]

23. opisk: hehehehheh£

24. ope: (selvä)

25. Meri: mut ku sen pointti on vähän ha[kuses]

26. ope: [ole] hyvä

Meri aloittaa kysymysvuoronsa nimeämällä yhden tenttikirjoista (r. 2-3) ja tuottaa sen jälkeen kysyvän vuoron (r. 3-5), joka muodostuu kahdesta rinnastuskonjunktion vai yhdistämästä vaihtoehtokysymyksestä sekä vai-konjunktiolla niihin kytketystä hakukysymyksestä. Merin kysymysvuoro tarjoaa siis opettajankouluttajalle kaksi vaihtoehtoista propositiota vahvistettavaksi ja osoittaa sitten hakukysymyksellä muiden mahdollisten vastausten olemassaolon. Vaihtoehtokysymykset hakevat tietoa kirjan asemasta suhteessa luentoihin (onks siit ollu jotain niinku tääl) ja sen roolista kurssin kokonaisuudessa laajemminkin (onkssejotenki niinku tukemas) ja kertovat siten myös opiskelijan tenttikirjallisuuteen liittyvistä taustaoletuksista. Hakukysymyksessä käytetty puhekielinen ilmaus pointti kuitenkin laajentaa kysyttävän alaa tenttikirjan sisältöön. ${ }^{3}$ Hakukysymyksen muotoilu ei siis anna yksiselitteistä vihjettä siitä, tulisiko odotuksenmukaisen vastauksen käsitellä kirjan roolia suhteessa kurssin muuhun opetukseen vai sen sisällön keskeisiä näkökohtia.

Opettajankouluttaja aloittaa vastausvuoronsa jo ennen kuin Meri on lopettanut, mutta ei vastaa kysymykseen vaan esittää kor-

\footnotetext{
3 Kielitoimiston sanakirjan mukaan pointti voi tarkoittaa esimerkiksi näkökohtaa, ratkaisevaa kohtaa tai asian ydintä.
} 
jausaloitteen (r. 6). Korjaussekvenssin jälkeen opettajankouluttaja esittää vastakysymyksen (r. 9-10), joka langettaa selontekovelvoitteen Merille. Vastakysymys on muotoiltu vahvistusta hakevaksi eikö-kysymykseksi, joka edellyttää vastaanottajalta samanmielisyyttä siitä, että kirjan käsittelemistä asioista on puhuttu luennoilla. Muotoilu implikoi, että opettajankouluttaja käsittelee asiaa jaettuna tietona, joka perustuu osallistujien yhteiseen kokemukseen luentosarjan tiimoilta ja siten kuuluu opiskelijoiden tiedolliselle reviirille. Näin opettajankouluttaja haastaa Merin kysymyksen oikeutuksen.

Opiskelija 2 antaa hiljaisella äänellä minimipalautteen, joka vahvistaa opettajankouluttajan esittämän proposition (r. 11), mutta nauhan perusteella on vaikeaa päätellä, kuuleeko opettajankouluttaja tätä vuoroa. Muutaman sekunnin mittaisen hiljaisuuden jälkeen opettajankouluttaja toistaa edellisessä vuorossa esittämänsä käsityksen hieman eri näkökulmasta (r. 13-14). Kielteinen väitelause asettaa epäilyksenalaiseksi sen, että kirjassa käsitellyt asiat toisivat mitään uutta suhteessa luennoilla käsiteltyihin, vaikkakin modaalinen partikkeli kai sen merkitsee puhujan subjektiiviseksi arvioksi tai oletukseksi (ei kai siel oo mitään niinku täysin, \#e- \#erinlaista; VISK §1603). Vuoron voi kuitenkin tulkita samanaikaisesti kysyväksi, sillä kysyttävä tieto on tavallaan peräisin yhteisestä lähteestä: molemmilla osapuolilla, opettajankouluttajalla ja opiskelijoilla, on yhtäläinen tiedollinen pääsy sekä kirjassa että luennoilla käsiteltyihin asioihin. Opiskelijan, joka on täyttänyt normatiiviset velvoitteensa opiskelijana eli osallistunut luennoille ja lukenut kurssikirjallisuuden, tulisi olla tietoinen siitä, että niiden sisällöt ovat keskenään yhdenmukaiset.

Opettajankouluttajan vuoroa seuraavan lyhyehkön hiljaisuuden jälkeen Meri esittää kaksi peräkkäistä vaihtoehtokysymystä (r. 16-17; onkse niinku <tutkimus> se kirja
$<$ kokonaisuudessaan> kertookse jostain sen tutkimuksesta), jotka sisältönsä puolesta lähestyvät kirjaa eri näkökulmasta kuin hänen sekvenssin alussa (r. 2-5) esittämänsä kysymys: tällä kertaa kysymykset käsittelevät tenttikirjan taustaa ja luonnetta, eivät sen roolia suhteessa kurssin muuhun opetukseen. Sekventiaalisen asemansa puolesta vuoron voi kuitenkin nähdä Merin yrityksenä muotoilla uudelleen kysymys, johon hän ei ole saanut riittävää vastausta: kysymys-vastaussekvenssissä vastausta seuraava kolmannen position vuoro on tyypillisesti paikka, jossa kysyjä voi kuitata vastauksen riittäväksi tai osoittaa sen riittämättömäksi (Merke, 2012).

Merin kysymystä seuraava pitkähkö, kahden sekunnin mittainen hiljaisuus (r. 18) ennakoi opettajankouluttajan käsittelevän sitä ongelmallisena, ja hiljaisuutta seuraakin vastakysymys (r. 19), joka asettaa Merin uudemman kerran selontekovelvolliseksi. Vuoro on muotoiltu kielteiseksi vaihtoehtokysymykseksi, joka vihjaa, ettei Meri ole edes nähnyt kirjaa. Meri kuitenkin kiistää opettajankouluttajan kysymyksen implikoiman epäilyksen ja ilmoittaa paitsi nähneensä kirjan, myös lukeneensa sen (r. 20). Rinnastuskonjunktio mutta osoittaa Merin olevan jatkamassa vuoroaan esittämällä jonkin aiemmin esiin tulleen tiedon valossa odotuksenvastaiseksi tai sen kanssa ristiriitaiseksi tulkittavissa olevan asiantilan, mutta vuoron jatko peittyy opiskelijoiden nauruun (r. 21-23). Nauru saattaa olla muiden opiskelijoiden reaktio jännitteeseen, joka syntyy opettajankouluttajan esittämän haasteen ja Merin puolustautumisen seurauksena. Kollektiivisella naurullaan muut opiskelijat voivat kääntää potentiaalisesti ongelmallisen tilanteen huvittavaksi ja siten ehkäistä ristiriidan kärjistymistä konfliktiksi (vrt. Petitjean \& Gonzales-Martinez, 2015.) Opettajankouluttaja ei jää odottamaan Merin vuoron jatkumista vaan merkitsee asian loppuun käsitellyksi tuottamalla sekvenssin 
sulkemista projisoivan ilmauksen selvä. Lopulta salissa kaikuvan naurun hiljennyttyä Meri jatkaa vuoroaan selonteolla sanomalla kirjan "pointin" jääneen kaikesta huolimatta epäselväksi. Opettajankouluttaja jättää kuitenkin Merin vuoron huomiotta ja antaa puheenvuoron seuraavalle opiskelijalle (r. 26) jo ennen kuin Meri on päässyt loppuun.

Edellä analysoidussa esimerkkikatkelmassa yliopisto-opintojensa alkutaipaleella oleva opiskelija ja kokenut opettajankouluttaja käyvät neuvottelua opiskelijan rooliin liittyvistä oikeuksia ja velvoitteita koskevista odotuksista. Katkelmaa edeltävä ja sitä seuraava keskustelu (ei näy litteraatissa) osoittavat, että opettajankouluttaja käsittelee ongelmattomina opiskelijoiden kysymyksiä esimerkiksi tenttivastausten pituudesta ja siitä, mitkä tenttikirjan lukuisista painoksista ovat riittävän ajankohtaisia. Näihin aihepiireihin liittyvien kysymysten ilmentämä tietämättömyys ei siis riko opiskelijan rooliin liittyviä episteemisiä ja moraalisia velvoitteita: ainakin opintojen tässä vaiheessa opiskelijoilla on oikeus olla tietämättä näitä asioita ja hakea niistä tietoa kysymällä.Sen sijaan Merin selityspyyntöä, jossa selitettäväksi määritellään tenttikirjan sisältö ja sen suhde luentoihin, opettajankouluttaja käsittelee opiskelijan rooliin liittyviin velvoitteisiin kohdistuvana norminrikkomuksena.

Tapa, jolla opettajankouluttaja vastaa opiskelijoiden kysymyksiin, välittää opiskelijoille tietoa siitä, millaisen tietämättömyyden osoittaminen on heille hyväksyttävää ja kenties kannustettavaakin, millaisen taas tuomittavaa. Esimerkkikatkelmamme opettajankouluttaja viestii toiminnallaan, että opiskelijoiden tulisi paitsi osallistua opetukseen ja tutustua kurssikirjallisuuteen, myös pystyä luomaan yhteyksiä luentojen ja tenttikirjallisuuden välille sekä tekemään selkoa lukemastaan kurssikirjallisuudesta itsenäisesti. Merin tuottamaa selityspyyntöä hän käsittelee osoituksena siitä, ettei tämä ole kyennyt täyttämään näitä opiskelijan rooliin liittyviä odotuksia. Toisaalta Merin selityspyynnön käsitteleminen ongelmallisena voi kuitenkin liittyä myös sen implikoimaan opettajankouluttajaan kohdistuvaan kritiikkiin. Opettajankouluttaja on nimittäin osaltaan vastuussa tenttikirjallisuuden valinnasta ja luentojen laatimisesta, ja opiskelijoiden vaikeudet tehdä selkoa niiden keskinäisestä suhteesta ja sisällöistä voivat vihjata paitsi opiskelijoiden haluttomuudesta tai kykenemättömyydestä ponnistella riittävästi oppimisensa eteen myös siitä, ettei opettajankouluttaja ole onnistunut täyttämään rooliaan opiskelijoiden oppimisen tukijana. Kyseenalaistamalla Merin selityspyynnön oikeutuksen opettajankouluttaja kuitenkin siirtää vastuun selityspyynnön implikoimista tietämiseen ja ymmärtämiseen liittyvistä ongelmista Merille.

\section{YHTEENVETO}

Tarkastelimme artikkelissamme opiskelijoiden selityspyyntöjä, pyyntöjen yhteydessä esitettyjä selontekoja sekä vastaanottajien tapaa käsitellä selityssekvenssin aloittavaa vuoroa. Olimme kiinnostuneita erityisesti selityspyyntöön liittyvän selonteon funktioista suhteessa kokonaistoimintaan ja sen päämäärään. Selonteolla selityksen pyytäjä voi perustella selityksen tarvetta. Selityspyyntöön liittyvä selonteko implikoi, ettei selityksen pyytäjä näe meneillään olevan kokonaistoiminnan itsessään tarjoavan riittävää tukea tai perustelua selityspyynnön tarpeellisuudelle tai oikeutukselle. Selityspyyntöön liittyvä selonteko antaakin vihjeen siitä, arvioiko selityspyynnön esittäjä pyyntöään tilanteessa potentiaalisesti ongelmallisena. Selonteolla selityksen pyytäjä voi osoittaa, miten selityspyyntö kytkeytyy meneillään olevaan toimintaan ja miten se palvelee (tai ei palvele) tilanteen päämäärää.

Esimerkeissä 1 ja 2 opiskelijan selityspyyntö johti selitystoimintaan, joka ratkaisi epäsel- 
vän kohdan. Esimerkissä 3 opiskelijan selityspyyntö taas sivuutettiin. Ensimmäisessä esimerkissä osallistujat osoittavat selitystoimintaan osallistumalla, että selityksen pyytäminen on hyväksyttävä ja norminmukainen toiminto. Selventämisen vastuu jakautuu kuitenkin kahdelle vastaajalle, mikä johtaa siihen, että sekvenssi ei etene tavanomaisesti: on päällekkäispuhuntaa ja sekaannusta siitä, kuka on seuraava puhuja ja vastuussa selityksestä. Loppujen lopuksi selityksen pyytäjä tyytyy selitykseen, joka ei kuitenkaan selitä ilmiötä kokonaisuudessaan. Toisessa esimerkissä mahdollisena kritiikkinä tulkittuun selityspyyntöön orientoidutaan odotuksenmukaisena niin, että opettaja osoittaa selonteollaan pyynnön oikeaksi ja oikeutetuksi metakommentilla. Samalla eksplikointi kuitenkin osoittaa opettajan käsittelevän opiskelijan tuottamaa selityspyyntöä tavalla tai toisella odotuksenvastaisena tai ongelmallisena. Toiminnallaan opettaja vahvistaa tietoa ja tietämistä koskevan valtajakauman: opettajalla on oikeus arvioida meneillään olevaa tilannetta ja kertoa, onko toiminta suhteessa kokonaistoimintaan hyväksyttävä vai ei. Kolmas esimerkki poikkeaa kulultaan kahdesta edeltävästä, sillä siinä opettajankouluttaja käsittelee opiskelijan tuottamaa selityspyyntöä ongelmallisena. Hän kyseenalaistaa opiskelijan oikeuden selityspyynnön esittämiseen vihjaamalla, että selityspyyntö rikkoo opiskelijan institutionaaliseen rooliin liittyviä episteemisiä ja moraalisia velvoitteita.

Selitysjaksojen analyysit toivat esille sen, että selityksen pyytäminen on luokkahuoneessakin henkilökohtainen projekti, josta aloitteentekijä kantaa vastuun ja jota luokkayhteisön jäsenet arvioivat oikeutetuksi, sallituksi ja hyväksyttäväksi - tai sitten eivät. Selityspyynnön pitää olla legitiimi vähintäänkin kahdella tasolla: ensinnäkin epäselvän kohdan eli selitettävän kohdan on oltava sidoksissa edelliseen vuoroon tai edelliseen sekvenssiin siinä mielessä, että edellinen vuoro tai sekvenssi joko sisältää epäselvän kohdan tai aiheuttaa muutoin toiminnan kannalta selventämisen tarpeen. Toiseksi selityksen pyytäjällä tulee olla oikeus keskeyttää sen hetkinen toiminta selityspyynnöllä: selityspyyntö, joka ei edistä kokonaistoimintaa tai joka arvioidaan muista syistä epäsopivaksi, voi saada osapuolilta - joko opettajalta tai toisilta opiskelijoilta - kielteisen vastaanoton.

Analyysimme osoitti, että episteemisyys ja siihen liittyvät normit ja moraalinen ulottuvuus tehdään näkyviksi jopa niin, että tiedolla tai tietämättömyydellä perustellaan pyynnön sivuuttamista. Selityspyyntö keskeyttää aina meneillään olevan toiminnan, avaa uuden toiminnan ja asettaa samalla pyynnön esittäjän keskiöön ja vastuuseen. Selonteolla selityspyynnön esittäjä voi selostaa normirikkomuksia sekä ennaltaehkäistä tai oikaista kanssakeskustelijan tulkintaa selityspyynnöstään. (Robinson, 2016). Tämä näyttääkin pätevän kaikkiin analysoimiimme opetuskeskusteluihin. Kaikissa niissä selonteko on tärkeä työkalu, jolla osoitetaan odotusten murtuneen tai jolla jälleenrakennetaan mahdollisesti kyseenalaistettua normiverkostoa (Robinson, 2016).

Koska ymmärtämistä tai ymmärtämättömyyttä ja niiden osoittamista käsitellään keskustelunanalyyttisessä kehyksessä ensisijaisesti sosiaalisena ja vuorovaikutuksellisena ilmiönä eikä kognitiivisena (Koole \& Elbers, 2014), selityssekvenssien analyysi paljastaa erityyppisiä sekvensseihin rakentuvia vuorovaikutuksellisia rajoitteita ja mahdollisuuksia. Kaikissa esimerkeissä selityspyynnöt ja niiden käsittely haastavat hetkellisesti ryhmän jäsenten yhteisymmärrystä. Lähtökohtaisesti voisi ajatella, että yhteisymmärrys perustuu vain selityspyynnön selkeään toiminnalliseen esittämiseen ja sopivaan ajankohtaan. Analyysistä käy kuitenkin ilmi, että hyvinkin erilaisissa aineistoissa yhteisymmärryksestä on 
neuvoteltava myös siitä näkökulmasta, onko selityspyyntö legitiimi ja oikeutettu toiminto ja onko se perusteltu hyväksyttävin kriteerein. Toimijuuden ja tietämisen vastuun lisäksi selitystoiminnassa yhtä tärkeitä ovat siis osallistujien arvioinnit siitä, toimivatko osallistujat "oikein" vai "väärin" (ks. myös Merke, 2016). Tietoisuus moraalista ilmenee vuorovaikutuksellisesti siten, että selityssekvenssin tyydyttävä loppuun saattaminen riippuu siitä, millaiseksi osallistujat arvioivat oman asemansa sekä oikeutensa toimia tilanteessa. Selityssekvenssin etenemiseen vaikuttaa myös se, miten osallistujat arvioivat selityspyynnön ajankohtaa, selityksen tarvetta ja selonteossa esiin tulleita perusteluja, täsmennyksiä tai kritiikkiä. Epäselväksi osoitetun seikan selventäminen saattaa vaatia uuden selityspyynnön, mikä voidaan tulkita norminylityksenä. Joissakin tapauksissa opettaja voi tehdä toiminnallaan selväksi, että hän on siirtynyt seuraavaan asiaan, jolloin selityksen pyytäjä voi myös luopua projektistaan.

\section{POHDINTA}

Selityspyynnöt voi luokitella toiminnoiksi, joiden avulla opiskelijat käsittelevät opetuksessa esille tulleita epäjohdonmukaisia ja selitystä tai selvennystä kaipaavia seikkoja. Kaikissa esittämissämme tapauksissa opiskelijat perustelivat tai selostivat selityspyyntöjä, joskin kolmannessa esimerkissä vasta sitten, kun pyynnön vastaanottaja - opettajankouluttaja - oli haastanut selityspyynnön oikeutuksen. Opiskelijoiden esittämät perustelut koskivat jonkin asian tai tilanteen osapuolen toiminnallista johdonmukaisuutta tai odotuksenvastaisuutta. Analyysit näyttivät sen, että opiskelijoilla on tietoa ja odotuksia siitä, miten asiat jäsentyvät oppitunnilla sekä yleisesti maailmassa. Selityspyynnöillä ja niiden yhteydessä esitetyillä selonteoilla opiskelijat tuovat esille, millaista johdonmukaisuutta he odottavat. Ensimmäisessä esimerkissä opiskelija pohtii kieliaineiden ja sanojen paradigmojen johdonmukaisuutta, kun taas toisessa esimerkissä opiskelija osoittaa, että tehtävänvastauksissa ja niiden arvioinnissa on oltava koherenssia. Kolmas esimerkki taas osoittaa, että itsenäisesti opiskeltavan kurssikirjallisuuden sekä luento- ja ryhmäopetuksen välinen suhteen oletetaan olevan ymmärrettävissä. Vaikka aineistomme edustavat hyvin erilaisia oppimiskonteksteja, analyysimme osoittavat, että tiedon yhteinen rakentaminen selityssekvenssin avulla noudattaa tiettyjä tunnistettavia mekanismeja kontekstista riippumatta.

Tutkimuksemme herättää kysymyksen selityspyyntöjen mahdollisuuksista tulla oppitunnilla käsitellyiksi. Analyysistämme kävi ilmi, että kaikissa analysoiduissa oppimiskonteksteissa selitystoimintaan liittyvä episteeminen ja moraalinen ulottuvuus on taustatekijä, joka vaikuttaa selitystoiminnan etenemiseen ja sen onnistumiseen (ks. myös Hazel \& Mortensen, 2017). Onnistuneessa selitysjaksossa sekventiaalinen, toiminnallinen ja tiedollinen oikeutus pyytää selitystä käyvät käsi kädessä. Tutkimissamme aineistoissa selityspyyntöjä käsitellään tunnusmerkittömänä ja oikeutettuna toimintana ainakin silloin, kun pyynnön nähdään palvelevan kokonaistoimintaa ja toiminnan päämäärää. Tähän liittyy esimerkiksi se, onko agendassa oppiaineen sisältöä koskevia vai opiskelukäytänteisiin liittyviä asioita ja sopiiko pyyntö agendan työvaiheeseen. Tilanteissa, joissa selityspyyntö on ristiriidassa toiminnan yleisen päämäärän kanssa (esim. kun joku pyytää tarkennusta sisällöllisiin asioihin silloin, kun keskustellaan proseduraalisista asioista tai toisinpäin), opettaja voi joko vahvistaa pyynnön oikeutetuksi tai hylätä sen. Opettaja voi myös arvioida selityksen agendan vaiheeseen nähden tarpeettomaksi (Skarbø-Solem, 2016). 
Tutkimuksemme jättää auki sen, millaisia norminylityksiä opiskelija varoo niin, että jättää esimerkiksi pyynnön kokonaan tekemättä. Taustalla saattaa vaikuttaa tietämiseen orientoitumisen kaksijakoisuus: opiskelijan selityspyyntö voi näyttäytyä liiallisena tiedonjanona tai toisaalta ongelmallisena tietämättömyytenä, jotka molemmat voivat johtaa pelkoon

\section{LÄHTEET}

Antaki, C. (1994). Explaining and arguing: The social organization of accounts. London: Sage Publications.

Candela, A. (1999). Students' power in classroom discourse. Linguistics and Education, 10, 139163.

Garfinkel,H.(1967). Studiesin Ethnomethodology. Cambridge: Polity Press.

Gosen, M.N., Berenst, J. \& de Glopper, K. (2013). The interactional structure of explanations during shared reading at kindergarten. International Journal of Educational Research, $62,62-74$.

Hakulinen, A. (2016). Lauserakenteet. Teoksessa M. Stevanovic \& C. Lindholm (toim.), Keskustelunanalyysi. Kuinka tutkia sosiaalista toimintaa ja vuorovaikutusta, (s. 122-142). Vastapaino: Tampere.

Hakulinen, A. \& E.-L. Seppänen (1992). Finnish kato: From verb to particle. Journal of Pragmatics, 18, 527-549.

Hazel, S. \& Mortensen, K. (2017). The classroom moral compass - participation, engagement and transgression in classroom interaction. Classroom Discourse, 8, 214-234.

Heller, V. (2017). Managing knowledge claims in classroom discourse: the public construction of a homogeneous epistemic status. Classroom Discourse, 8, 156-174.

Heinonen, P. (2017). Evaluointi opettajan vuorovaikutustoimintana: osallistujuuden ulottuvuudet luokkahuoneessa. Helsinki: Helsingin yliopisto. sosiaalisesta stigmatisoitumisesta ja ryhmän ulkopuolelle jäämisestä. Kolmannen esimerkin analyysi osoitti, että selontekovelvollisuus ja vastuu pysyvät voimassa koko toiminnan ajan. Pohdiskeltavaksi siis jää, kuinka hyvin osallistujat pystyvät neuvottelemaan tiedollisesta ja toiminnallisesta vastuusta itse keskustelutilanteessa.
Heritage, J. (1984). Garfinkel and ethnomethodology. Cambridge: Polity Press.

Heritage, J. (1988). Explanations as accounts: A conversation analytic perspective. Teoksessa C. Antaki (toim.), Analysing Everyday Explanation: A Casebook of Methods, (s. 127144). London: Sage.

Heritage, J. (2012). Epistemics in Action: Action Formation and Territories of Knowledge. Research on Language and Social Interaction, 45, 1-29.

Jacknick, C. (2011). Breaking in is hard to do: how students negotiate classroom activity shifts. Classroom Discourse, 2, 20-38.

Jakonen, T. (2014a). Knowing matters: How students address lack of knowledge in bilingual classroom interaction. Jyväskylä: Jyväskylän yliopisto.

Jakonen T. (2014b). Building bridges. How secondary school pupils bring their informal learning experiences into a Content and Language Integrated (CLIL) classroom. Apples: Journal of Applied language studies, 8, 7-28.

Karvonen, U., Tainio, L., Routarinne, S. \& Slotte, A. (2015). Tekstit selitysten resursseina oppitunnilla. Puhe ja kieli, 35, 187-209.

Kääntä, L. (2014). From noticing to initiating correction: Students' epistemic displays in instructional interaction. Journal of Pragmatics, 66, 86-105.

Koole, T. (2010). Displays of epistemic access: Student responses to teacher explanations. Research on Language and Social Interaction, 43, 183-209. 
Koole, T. \& Elbers, E. (2014). Responsiveness in teacher explanations: A conversation analytical perspective on scaffolding. Linguistics and Education, 26, 57-69.

Lawrence, S. G. (1996). Normalizing stigmatized practices: Achieving co-membership by doing being ordinary. Research on Language and Social Interaction, 29, 181-218.

Lehtimaja, I. (2012). Pubeen suuntia luokkahuoneessa: Oppilaat osallistujina yläkoulun suomi toisena kielenä -tunnilla. Helsinki: Helsingin yliopisto.

Majlesi, A. R. \& M. Broth (2012). Emergent learnables in second language classroom interaction. Learning, Culture and Social Interaction, 1, 193-207.

Melander H. \& Sahlström F. (2009). In tow of the blue whale: Learning as interactional changes in topical orientation. Journal of Pragmatics, 41, 1519-1537.

Merke, S. (2012). Kielen opiskelu ja tunteet: Affekti jäsentämässä opiskelijoiden aloittamia kysymyssekvenssejä vieraan kielen oppitunneilla. Virittäjä, 116, 198-230.

Merke, S. (2016). Opiskelijoiden aloittamat kysymyssekvenssit oppitunnin voimavarana. Helsinki: Helsingin yliopisto.

Morek, M. (2012). Kinder erklären. Interaktion in Familien und Unterricht im Vergleich. Tübingen: Stauffenberg.

Nordlund, T. (2011). Perustelevasta referoivaksi: Suomen partikkelin muka merkityksenmuutos 1800-luvun tekstiaineistojen valossa. Virittäjä, 115, 484-514.

Petitjean, C. \& Gonzales-Martinez, E. (2015). Laughing and smiling to manage trouble in French-language classroom interaction. Classroom Discourse, 6, 89-106.

Raevaara, L. (2016). Toimintajaksojen rakenteet. Teoksessa: C. Lindholm ja M. Stevanovic (toim.), Keskustelunanalyysi. Kuinka tutkia sosiaalista toimintaa ja vuorovaikutusta, (s. 143-161). Tampere: Vastapaino.

Robinson, J. D. (2016). Accountability in social interaction. Teoksessa J.D. Robinson (toim.), Accountability in Social Interaction, (s. 1-44). Oxford: Oxford University Press.

Schegloff, E. A. (2007). Sequence organization in interaction: A primer in conversation analysis $I$ (Vol. 1). Cambridge: Cambridge University Press.
Sidnell, J., \& Stivers, T. (toim.) (2012). The Handbook of Conversation analysis (Vol. 121). West Sussex, UK: John Wiley \& Sons.

Skarbø Solem, M. (2016). Negotiating knowledge claims: Students assertions in classroom interaction. Discourse Studies, 18, 737-757.

Stevanovic, M., \& Lindholm, C. (2016). Keskustelunanalyysi. Kuinka tutkia sosiaalista toimintaa ja vuorovaikutusta. Tampere: Vastapaino.

Stevanovic, M., \& Peräkylä, A. (2014). Three orders in the organization of human action: On the interface between knowledge, power, and emotion in interaction and social relations. Language in Society, 43, 185-207.

Stivers, T., Mondada, L. \& Steensig, J. (2011). Knowledge, morality and affiliation in social interaction. Teoksessa T. Stivers, L. Mondada \& J. Steensig (toim.), The Morality of Knowledge in Conversation, (s. 3-26). Cambridge: Cambridge University Press.

Tanner, M. (2017). Taking interaction in literacy events seriously: a conversation analysis approach to evolving literacy practices in the classroom. Language and Education, 31, 400417.

Thornborrow, J. (2002). Power talk. Language and Interaction in Institutional Discourse. London: Longman.

Tainio, L. (2007). Miten tutkia luokkahuoneen vuorovaikutusta keskustelunanalyysin keinoin. Teoksessa L. Tainio (toim.) Vuorovaikutusta luokkahuoneessa. Näkökulmana keskustelunanalyysi, (s. 15-58). Helsinki: Gaudeamus.

Waring, H.Z. (2011). Learner initiatives and learning opportunities in the language classroom. Discourse Studies, 2, 201-218.

VISK (2004). Toim. A. Hakulinen, I. Alho, T. R. Heinonen, V. Koivisto, R. Korhonen, M. Vilkuna. Iso suomen kielioppi. Helsinki: Suomalaisen Kirjallisuuden Seura. Saatavilla: http://scripta.kotus.fi/visk/etusivu.php 


\section{STUDENTS' SELF-INITIATED REQUESTS FOR EXPLANATION AND THEIR TREATMENT: NEGOTIATIONS ON THE EPISTEMIC RIGHTS AND RESPONSIBILITIES IN CLASSROOM INTERACTION}

Saija Merke, Åbo Akademi University

Pilvi Heinonen, University of Helsinki

Ulla Karvonen, University of Helsinki

The study deals with students' requests for explanation and accounts that link to the requests. The data consist of three different data sets, two coming from the university context and one from Finnish high school classes. The research method adopted is ethnomethodological conversation analysis. The analysis is based on the explanation sequence that is presented as an action-driven and epistemic sequence. The participants address the request as a non-marked and justified turn in talk when the request fits to the sequential context and advances the larger activity. The study focuses on requests that are accompanied by accounts. Moreover, the requester or requestee may deal with the request turn as an unexpected and as such norm violating turn. One central finding is that participants use accounts to negotiate the epistemic and moral responsibility of requests for explanations. The legitimacy of the explanation request influences the successful closure of the explanation sequence.

Keywords: accounts, classroom interaction, epistemic rights, requests for explanation 